\title{
GEOGRAPHICAL STRATIFICATION BY SOCIO-ECONOMIC STATUS: METHODOLOGY FROM A HOUSEHOLD SURVEY WITH ELDERLY PEOPLE IN S. PAULO, BRAZIL
}

\author{
Luiz Roberto Ramos* \\ Samuel Goihman**
}

\begin{abstract}
RAMOS, L.R. \& GOIFIMAN, S. Geographical stratification by socio-economic status: methodology from a household survey with elderly people in S. Paulo, Brazil. Rev. Saúde públ., S. Paulo, 23: 478-92, 1989.

ABSTRACT: Considering that in most developing countries there are still no comprehensive lists of addresses for a given geographical area, there has always been a problem in drawing samples from the community, ensuring randomisation in the selection of the subjects. This article discusses the geographical stratification by socio-economic status used to draw a multistage random sample from a community-based elderly population living in a city like S. Paulo - Brazil. Particular attention is given to the fact that the proportion of elderly people in the total population of a certain area appeared to be a good discriminatory variable for such stratification. The validity of the stratification method is analysed in the light of the socio-economic results obtained in the survey.
\end{abstract}

KEYWORDS: Urban population. Aged. Sampling. Studies. Methods. Socio-economic factors.

\section{INTRODUCTION}

In 1984, a household survey was conducted in the City of S. Paulo (Brazil), aiming at an assessment of health status and social support of elderly people living in the community (Ramos, 1987). It was the first population-based study of elderly people in the country which used a multidimensional functional assessment questionnaire to produce a general profile of the elderly living in an urban centre like S. Paulo. The study required a community sample to be stratificd according to the socio-economic status of the respondent, as the main hypothesis was that socioeconomic differences account for most of the variation in terms of physical and mental health status, social support, and perceived well-being in old age.

Thus, there was the need for a systematisation of the urban space to enable a correct interpretation of people's living conditions to be made. It was necessary to identify innor areas, within the urban area of S. Paulo, inhabited predominantly by people of the same socio-economic status.

On the other hand, population based studies in a city like S. Paulo have always been a great problem. As well as the difficulties caused by the size of the population and the continuous migration flow, there has never been a systematic register of the inhabitants of the city in such as to make it possible to produce a comprehensive and updated list of names and add resses such as the English electoral roll. This is a problem that affects most Third World Countries and at the present time hinders the drawing of such samples from the community as would ensure randomization in the selection of households or subjects. This article expounds the methodology used in the study, first, to stratify the city of S. Paulo in three different, geografically defined socio-economic strata and, sccond, to draw a random sample of people aged 65 and over living in the community. Finally,

- Setor de Geriatria e Gerontologia da Escola Paulista de Medicina - Rua Botucatu, 740 - 04023 - São Paulo; SP - Brasil; Cooordenaçăo do Programa de Saúde do Idoso da Secretaria de Estado da Saúde de Săo Paulo - Av. Dr. Amaldo, 351 . 01246 - São Paulo, SP - Brasil.

Centro de Informação em Saúde da Secretaria de Estado da Saúde de Săo Paulo - Av. Dr. Arnaldo, 351 - 01246 - Såo Paulo, SP - Brasil; Centro de Informática em Saúde da Escola Paulista de Medicina - Rua Botucatu, 740 - 04023 - São Paulo, SP - Brasil. 
some of the data collected in the study are analysed on the light of the socio-economic stratification in order to discuss the validity of the methodology used.

\section{Characteristics of the city of S. Paulo}

The city of S. Paulo is a constantly growing urban centre which bloomed with the growth of the coffee business early this century. Since the 1940 s, however, it has become the main industrial center of the country, in which $11 \%$ of the economically active population of the country is concentrated and accounts for more than $35 \%$ of the Gross National Product (IBGE 5 , 1984). Such a concentration of wealth and manpower has made S. Paulo one of the main 'receiving' areas in the country for the internal migration flows from the North and North-Eastern regions. As a consequence the population of the city of S. Paulo has increased exponentially. A comparativelly small city in 1920, with little more than five hundred thousand people, it has become the largest city of the country and the fifth largest city in the world.

Nowadays the city of $S$. Paulo has a dense population of more than 12 million people living in an area of 1493 sq.Km (SEADE $\left.{ }^{6}, 1987\right)$. It is also the city in Brazil where the ageing process is most advanced, considering the mortality and fertility rates that determine the demographic transition (Ramos et al. ${ }^{11}$, 1987; Kalache et al. ${ }^{8}, 1987$; Veras et al. $\left.{ }^{14}, 1987\right)$. Almost $6 \%$ of the population is aged 65 and over, despite the influx of young migrants, and in some areas of the city this proportion rises to $10 \%$. What seems most important, however, when thinking about sampling for a household survey like the one proposed above, is the duality presented by S. Paulo's population. On the one hand there is a population living in the centre of the city, which enjoys comparatively good health and reasonable standards of living - a result to be expected in the light of the economic growth associated with industrial development. On the other hand, in the peripheral areas, the majority of the population are very poor, recently settled, living in rudimentary slums, without sanitation, and usually far from the nearest health or social facility. This latter situation seems to be the inevitable outcome of the present mode of production that has promoted industrial development at the cost of keeping the majority of the population below the poverty level.
Indicators for the Socio-Economic Stratification of the Population

In 1974 a survey, designed to assess the population's transport habits, produced the first stratification of S. Paulo's population by socioeconomic status, using as stratification units the districts and sub-districts of the City (geographically and administrativelly defined areas, equivalent to Boroughs in the UK) (Fig. 1), and as discriminative variables a set of social and health indicators - average family income, infant mortality rates, availability of sanitation and public health facilities (Governo do Estado de S. Paulo? 1976). A multivariate analysis grouped the districts and sub-districts in 3 'homogeneous areas', revealing adjacent and concentric central, intermediate and peripheral areas. The findings confirmed the duality described above - infant mortality rates and low income families increased from the centre to the outskirts of the city, whereas the availability of sewers decreased from the centre outwards. However, as pointed out by

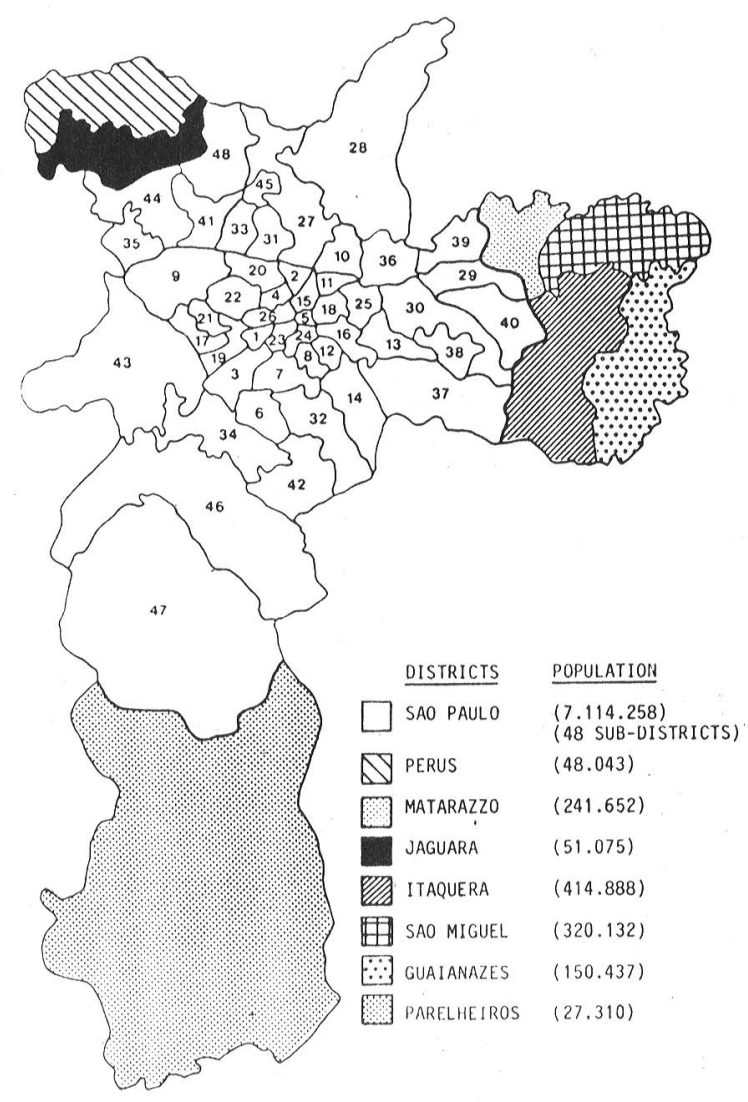

Fig. 1 - City of S. Paulo and its 8 districts and 48 sub-districts (1980 Census). 
Monteiro et al. ${ }^{9}$ (1980), some variables considered alone have shown a very poor discriminative power. That was the case, for instance, for the variable water supply, which has recently became available to almost every neighbourhood, and thus lost its power as a socio-economic indicator. Bearing this previous stratification in mind, it was necessary to update the indicators through the 1980 census, using only those that have shown good discriminatory power, such as family income and availability of sewers. Census data for the city of S. Paulo identified the district of S. Paulo and its 48 sub-districts, but not the other 7 districts comprising the city, as shown in Figure 1. For that reason the study covered the district and not the whole city of S. Paulo.

\section{Family Income and Availability of Sewers}

The 1980 Census figures give data on the average family income and the percentage of households with sewers in each of the sub-districts of the district of S. Paulo. Both the average family income and the percentage of households with sewers, varied greatly from one Sub-district to another. For instance, in the richest sub-district the average family income was $\mathbf{1 8 . 5}$ times the minimum salary (MS) (US\$ 1,410 ), whereas in the poorest it was less than 4 times the MS (USS 295) (Table 1). In terms of the coverage of the sewage system the situation was even more uneven, the affluent sub-districts giving more than $97 \%$ of the houses as served by the system, whereas at the poorest end of the spectrum, there were sub-districts in which less than $20 \%$ of the households were provided with sewers (Table 2). Considering that the highest income group defined in the census was an open ended group (20 or more MS), it was decided to use the median instead of the mean to indicate the average family income in each sub-district. The sub-districts were, then, ranked by the median family income (from the highest income to the lowest) and by the availability of sewers (from the highest percentage of households with sewers to the lowest). The sub-district representing the median value was used to calculate terciles, thus dividing the 48 sub-districts into 3 groups (with 16 sub-districts

TABLE 1

Median family income (US\$) in the 48 sub-districts of S. Paulo, 1980.

(First tercile -16 sub-districts)

(Second tercile - 16 sub-districts)

(Third tercile -16 sub-district)

\begin{tabular}{clcclcclc}
\hline Rank & Sub-district & US\$ & Rank & Sub-district & US\$ & Rank & Sub-district & US\$ \\
\hline 1 & J. América & 1,405 & 17 & Bom Retiro & 565 & 33 & Penha & 426 \\
2 & J. Paulista & 1,358 & 18 & Pari & 545 & 34 & Brás & 409 \\
3 & Cerqueira César & 1,236 & 19 & Barra Funda & 543 & 35 & Tucuruví & 387 \\
4 & Indianópolis & 1,192 & 20 & Moóca & 533 & 36 & Limão & 386 \\
5 & Vila Mariana & 1,081 & 21 & Belenzinho & 524 & 37 & Jabaquara & 383 \\
6 & Ibirapuera & 1,060 & 22 & Liberdade & 521 & 38 & Vila Maria & 379 \\
7 & Pinheiros & 1,053 & 23 & Alto do Moóca & 518 & 39 & Pirituba & 377 \\
8 & Perdizes & 1,009 & 24 & Ipiranga & 517 & 40 & Vila Prudente & 372 \\
9 & Vila Madalena & 939 & 25 & Sé & 508 & 41 & Vila Formosa & 369 \\
10 & Aclimação & 784 & 26 & Vila Guilherme & 485 & 42 & N. Sra. do “O”. & 366 \\
11 & Consolação & 784 & 27 & Santana & 477 & 43 & Cangaíba & 356 \\
12 & Santa Cecília & 747 & 28 & Tatuapé & 470 & 44 & Vila Matilde & 352 \\
13 & Lapa & 686 & 29 & Santa Efigênia & 468 & 45 & Santo Amaro & 344 \\
14 & Bela Vista & 678 & 30 & Butantan & 455 & 46 & V.N. Cachoeirinha & 337 \\
15 & Cambuci & 622 & 31 & Jaguara & 442 & 47 & Capela do Socorro & 309 \\
16 & Saúde & 565 & 32 & Casa Verde & 429 & 48 & Brasilândia & 295 \\
\hline
\end{tabular}

Source: IBGE $^{3}$ (1983)

- In Brazil, due to inflation, income data are usually presented in terms of multiples of the Minimum Salary which is regulated by law as the bottom of the salary scale and supposed to keep pace with inflation. One Minimum Salary in 1980 was equivalent to approximately US\$ 75 per month. 


\section{TABLE 2}

Availabity of sewers ( $\%$ of households) in the 48 sub-districts of S. Paulo, 1980

\begin{tabular}{|c|c|c|c|c|c|c|c|c|}
\hline \multicolumn{3}{|c|}{ (First tercile -16 sub-districts) } & \multicolumn{3}{|c|}{ (Second tercile -16 sub-districts) } & \multicolumn{3}{|c|}{ (Third tercile - 16 sub-districts) } \\
\hline Rank & Sub-district & $\begin{array}{c}\% \\
\text { Households } \\
\text { with sewers }\end{array}$ & Rank & Sub-district & $\begin{array}{c}\% \\
\text { Households } \\
\text { with sewers }\end{array}$ & Rank & Sub-district & $\begin{array}{c}\% \\
\text { Households } \\
\text { with se wers }\end{array}$ \\
\hline 1 & Indianópolis & 97.2 & 17 & Sé & 89.5 & 33 & Tatuapé & 62.3 \\
\hline 2 & Consolação & 97.2 & 18 & Belenzinho & 88.3 & 34 & N. Sra. do " $O$ " & 62.3 \\
\hline 3 & Cerqueira César & 97.1 & 19 & Bom Retiro & 87.8 & 35 & Butantan & 60.3 \\
\hline 4 & Jardim Paulista & 96.3 & 20 & Liberdade & 87.0 & 36 & Vila Gưilherme & 56.4 \\
\hline 5 & Pinheiros & 96.2 & 21 & Barra Funda & 86.4 & 37 & V. N. Cachoeirinha & 55.5 \\
\hline 6 & Perdizes & 94.5 & 22 & Moóca & 86.2 & 38 & Tucuruvi & 44.0 \\
\hline 7 & Santa Cecília & 94.1 & 23 & Casa Verde & 84.9 & 39 & Penha & 41.0 \\
\hline .8 & Bela Vista & 93.6 & 24 & Ibirapuera & 83.7 & 40 & Vila Prudente & 41.0 \\
\hline 9 & Vila Mariana & 93.1 & 25 & Alto da Moóca & 80.1 & 41 & Vila Maria & 39.9 \\
\hline 10 & Aclimação & 92.5 & 26 & Brás & 79.9 & 42 & Vila Matilde & 39.5 \\
\hline 11 & Vila Madalena & 92.1 & 27 & Limão & 78.0 & 43 & Brasilândia & 37.6 \\
\hline 12 & Jardim América & 91.5 & 28 & Ipiranga & 76.5 & 44 & Santo Amaro & 31.4 \\
\hline 13 & Santa Efigênia & 91.5 & 29 & Santana & 73.1 & 45 & Capela do Socorro & 28.6 \\
\hline 14 & Pari & 91.4 & 30 & Saúde & 73.0 & 46 & Pirituba & 24.3 \\
\hline 15 & Lapa & 91.0 & 31 & Jaguara & 68.2 & 47 & Cangaiba & 20.3 \\
\hline 16 & Cambuci & 90.3 & 32 & Jabaquara & 66.2 & 48 & Vila Formosa & 19.7 \\
\hline
\end{tabular}

Source:IBGE ${ }^{3}$ (1983)

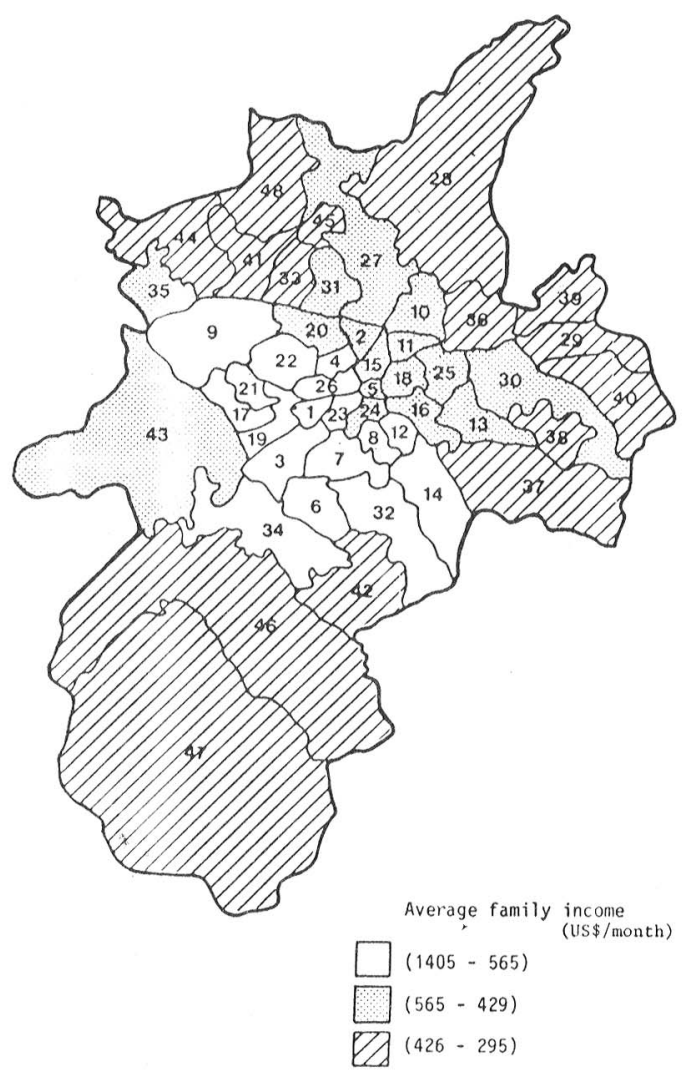

Fig. 2 - Division of the District of S. Paulo ( 48 sub-districts) in 3 areas (16 sub-districts eachs) according to the average family income (USS) of each sub-district.

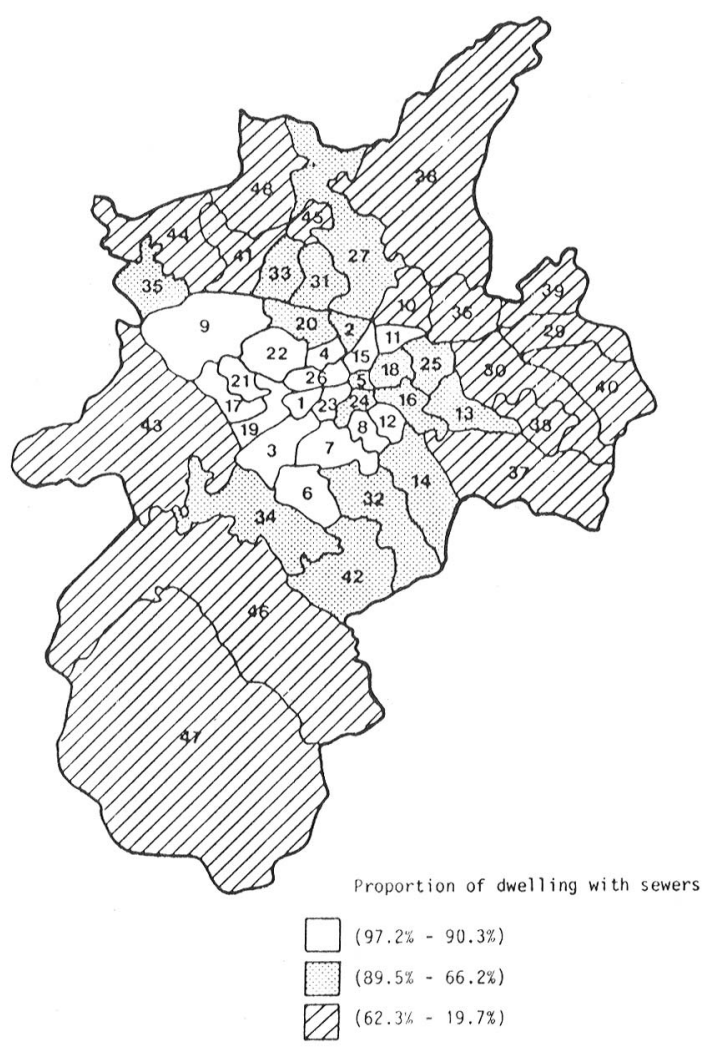

Fig. 3 - Division of the District of S. Paulo (48 sub-districts) in 3 areas (16 sub-districts each) according to the proportion of dwellings with sewers in each sub-district. 
TABLE 3

Proportion of elderly (65 years or more) in the total population in 48 sub-districts of S. Paulo, 1980

\begin{tabular}{|c|c|c|c|c|}
\hline Rank & Sub-district & $\begin{array}{c}\text { Total } \\
\text { Population }\end{array}$ & $\begin{array}{l}\text { Population } \\
65 \text { Years } \\
\text { and over }\end{array}$ & $\begin{array}{c}\% \\
65 \text { Years } \\
\text { and over }\end{array}$ \\
\hline 1 & Consolação & 72,372 & 6,450 & 8.91 \\
\hline 2 & Belenzinho & 49,273 & 4,365 & 8.86 \\
\hline 3 & Bom Retiro & 25,068 & 2,136 & 8.52 \\
\hline 4 & Sta. Cecília & 84,956 & 7,001 & 8.24 \\
\hline 5 & V. Mariana & 108,282 & 8,899 & 8.22 \\
\hline 6 & Pari & 27,748 & 2,282 & 8.22 \\
\hline 7 & C. César & 65,447 & 5.338 & 8.16 \\
\hline 8 & Aclimação & 55,364 & 4,493 & 8.12 \\
\hline 9 & B. Funda & 30,685 & 2,474 & 9.06 \\
\hline 10 & Cambuci & 53,590 & 4,238 & 7.91 \\
\hline 11 & J. Paulista & 116,450 & 8,956 & 7.70 \\
\hline 12 & Pinheiros & 47,129 & 3,582 & 7.60 \\
\hline 13 & Moóca & 36,175 & 2,730 & 7.55 \\
\hline 14 & J. América & 55,291 & 4,143 & 7.50 \\
\hline 15 & Lapa & 135,515 & 9,878 & 7.29 \\
\hline 16 & Perdizes & 127,935 & 9,257 & 7.24 \\
\hline 17 & Bela Vista & 79,367 & 5,670 & 7.14 \\
\hline 18 & A Moóca & 136.433 & 9,340 & 6.85 \\
\hline 19 & Indianópolis & 82,658 & 5,468 & 6.62 \\
\hline 20 & Sé & 8,207 & 537 & 6.54 \\
\hline 21 & Sta. Efigênia & 42,551 & 2,776 & 6.52 \\
\hline 22 & Brás & 48,588 & 3,145 & 6.47 \\
\hline 23 & Ipiranga & 179,353 & 10,950 & 6.11 \\
\hline 24 & V. Madalena & 48,296 & 2,784 & 5.76 \\
\hline 25 & Penha & 142,656 & 7,882 & 5.53 \\
\hline 26 & Liberdade & 73,383 & 4,050 & 5.52 \\
\hline 27 & Tatuapé & 279,357 & 14,601 & 5.22 \\
\hline 28 & Saúde & 289,027 & 14,609 & 5.05 \\
\hline 29 & C. Verde & 110,634 & 5,441 & 4.92 \\
\hline 30 & V. Guilherme & 77,120 & 3,645 & 4.73 \\
\hline 31 & Ibirapuera & 158,415 & 7,386 & 4.66 \\
\hline 32 & Santana & 274,101 & 12,442 & 4.54 \\
\hline 33 & V. Maria & 131,851 & 5,437 & 4.12 \\
\hline 34 & Tucuruvi & 463,262 & 17,915 & 3.87 \\
\hline 35 & V. Formosa & 119,704 & 4,544 & 3.80 \\
\hline 36 & Limão & 86,034 & 3,230 & 3.75 \\
\hline 37 & V. Prudente & 496,537 & 17,667 & 3.56 \\
\hline 38 & V. Jaguara & 71,641 & 2,522 & 3.52 \\
\hline 39 & Cangaiba & 75,244 & 2,604 & 3.46 \\
\hline 40 & Pirituba & 117,773 & 4,064 & 3.45 \\
\hline 41 & N. Sra. do "O" & 173,856 & 5,964 & 3,43 \\
\hline 42 & Jabaquara & 266,906 & 8,610 & 3.23 \\
\hline 43 & V.N. Cachoeira & 37,411 & 1,195 & 3.19 \\
\hline 44 & V. Matilde & 239,739 & 7,637 & 3.17 \\
\hline 45 & Butantã & 318,421 & 9,576 & 3.01 \\
\hline 46 & Sto. Amaro & 765,743 & 17,554 & 2.29 \\
\hline 47 & Brasilândia & 176,269 & 3,455 & 1.96 \\
\hline 48 & C. Socorro & 452,041 & 7,707 & 1.70 \\
\hline
\end{tabular}

Source:IBGE ${ }^{1,2}(1973,1983)$

each). The geographical areas representing the 3 strata following both, the values for family income and availability of sewers per sub-district (Figures 2 and 3 respectively) showed a very similar picture to the one obtained in the previous study metioned above - three adjacent and concentric areas.
Proportion of Elderly Residents as a Stratification Variable

A striking early finding of the present study was the pattern of distribution of the elderly in the city. Most central areas showed an above the average proportion of elderly people, unless the 


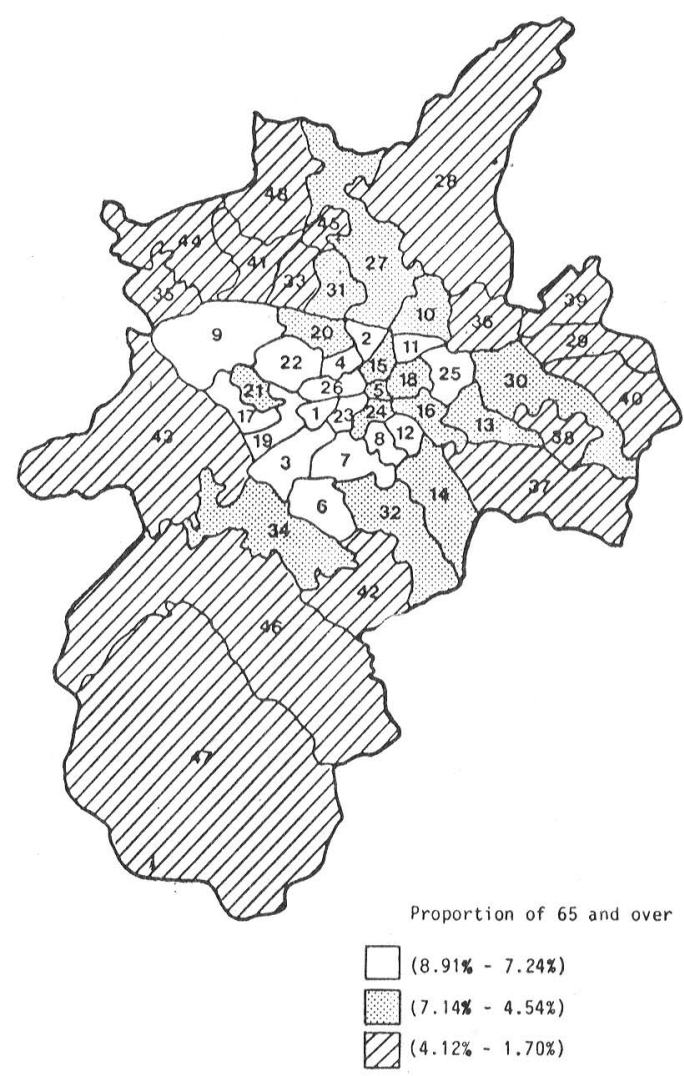

Fig. 4- Division of the District of S. Paulo (48 sub-districts) in 3 areas (16 sub-districts each) according to the proportion of people of 65 and over in the total population of each sub-district.

area had experienced a socio-economic decline in which case the proportion of elderly tended to be below the average for the city. In most peripheral areas the proportion of elderly people in the total population was substantially below the average. An important finding, however, was the strong association between the proportion of elderly people in the total population and the socio-economic indicators previously used to stratify the city in homogeneous areas. The sub-districts with the highest proportions of elderly in the total population were in most cases the ones with the highest average incomes. The variable proportion of elderly in the total population had, in fact, shown a direct and highly significant statistical correlation with both variables, family income and availability of sewers (elderly/income $\mathrm{rs}=$ 0.83 and elderly/sewers $\mathrm{rs}=0.81$ ). Such correlations suggested a new stratification of the popu- lation using the proportion of elderly people as one of the stratification variables.

Table 3 shows the ranking of the 48 sub-districts, according to the percentage of elderly in the total population. The three groups (16 subdistricts each), representing populations with high, median and low proportion of elderly in the total population, had adjacent and concentric areas as described above. The geographical division, as seen in Figure 4, closely resembled the previous ones which used income and sewers as indicators. The proportion of elderly people increased from the periphery to the centre, along with the average family income and the availability of sewers. The elderly themselves seemed, in fact, to be a reasonably good indicator of the socio-economic situation of a particular population. In some central sub-districts, where the socio-economic situation has deteriorated in the last decades, the proportion of elderly people was much lower than one would have expected considering, for instance, the good availability of sanitation in these areas. That seemed to indicate that the proportion of elderly people in the total population can be a more dynamic indicator than sewers, because the elderly are likely to migrate when the socio-economic situation worsen, whe reas the sewers, once they are introduced need only maintenance and therefore their distribution remains the same.

\section{Differential Ageing in S. Paulo's Sub-districts}

The study of the functional status of an elderly urban population requires a broader understanding of the dynamics of the segregation of the urban space. A detailed analysis of the population changes in each of the 48 sub-districts of $S$. Paulo was undertaken for sampling purposes, in the period between the censuses of 1970 and 1980. Table 4, shows the variations of the total and elderly populations in each sub-district of S. Paulo over the decade.

There are large disparities both in the proportion of elderly ( 60 and over) in the total population and in the rates of increase of the population in the various sub-districts. The proportion of elderly, for instance, ranges from a maximum of $13.1 \%$ (see n. 25 ) to a minimum of $2.9 \%$ of the total population (see n. 52) - the average for the city being $6.4 \%$, in 1980 . And, as mentioned above, there seemed to be a pattern of variation in which the wealthier and more urbanised areas contained proportionately more elderly people, 
TABLE 4

Percentual increases of the total and 60 and over populations in each sub-district of S. Paulo in the 1970-1980 decade.

\begin{tabular}{|c|c|c|c|c|c|c|}
\hline & \multirow[b]{2}{*}{ Sub-district } & \multicolumn{3}{|c|}{ Population } & \multicolumn{2}{|c|}{$\begin{array}{c}\text { Variation } \\
\text { between } \\
1970-1980 \\
(\%)\end{array}$} \\
\hline & & $\begin{array}{l}\text { total } \\
(1980)\end{array}$ & $\begin{array}{c}60+ \\
(1980)\end{array}$ & $\begin{array}{c}60+/ \text { tot } \\
(\%)\end{array}$ & $\begin{array}{l}\text { total } \\
\text { pop. }\end{array}$ & $\begin{array}{l}60+ \\
\text { pop. }\end{array}$ \\
\hline 1 & C. César & 65.447 & 7,722 & 11.79 & 50.0 & 62.7 \\
\hline 2 & Bom Retiro & 25,068 & 2,964 & 11.82 & -2.1 & -2.2 \\
\hline 3 & J. Paulista & 116,450 & 13,127 & 11.27 & 26.7 & 49.4 \\
\hline 4 & Sta. Cecília & 84,956 & $10,229^{\circ}$ & 12.04 & 31.8 & 39.4 \\
\hline 5 & Sé & 8,207 & 854 & 10.40 & 7.6 & 6.9 \\
\hline 6 & Indianópolis & 82,658 & 8,156 & 9.86 & 16.9 & 46.8 \\
\hline 7 & V. Mariana & 108,282 & 12,886 & 11.90 & 43.0 & 41.5 \\
\hline 8 & Aclimação & 55,364 & 6,573 & 11.87 & 12.8 & 30.1 \\
\hline 9 & Lapa & 135.515 & 14,590 & 9.19 & 10.6 & 28.9 \\
\hline 10 & V. Guilherme & 77.120 & 5,708 & 7.40 & 14.4 & 30.8 \\
\hline 11 & Pari & 27,748 & 3,367 & 12.13 & -9.6 & 1.8 \\
\hline 12 & Cambuci & 63,590 & 6,186 & 11.54 & 10.3 & 18.9 \\
\hline 13 & A. Moóca & 136,433 & 14,124 & 10.35 & -0.4 & 29.2 \\
\hline 14 & Ipiranga & 179,353 & 16,649 & 9.28 & 4.7 & 24.9 \\
\hline 15 & Sta. Efigênia & 42,551 & 4,177 & 9.81 & 14.5 & 3.1 \\
\hline 16 & Moóca & 36,175 & 4,067 & 11.24 & 2.5 & 3.5 \\
\hline 17 & Pinheiros & 47,129 & 5,297 & 11.23 & 13.9 & 31.6 \\
\hline 18 & Brás & 48,588 & 4,809 & 9.89 & -10.7 & -16.7 \\
\hline 19 & J. América & 55,291 & 6,113 & 11.05 & 17.1 & 35.9 \\
\hline 20 & B. Funda & 30,685 & 3,615 & 11.78 & 3.1 & 7.9 \\
\hline 21 & V. Madalena & 48,296 & 4,068 & 8.42 & 56.8 & 71.6 \\
\hline 22 & Perdizes & 127,935 & 13,653 & 10.67 & 27.7 & 40.3 \\
\hline 23 & Bela Vista & 79,367 & 8,164 & 10.28 & 29.7 & 29.3 \\
\hline 24 & Liberdade & 73,383 & 6,227 & 8.48 & 22.7 & 24.5 \\
\hline 25 & Belenzinho & 49,273 & 6,446 & 13.08 & -5.7 & 7.1 \\
\hline 26 & Consolação & 72,372 & 9,294 & 12.84 & 16.3 & 33.7 \\
\hline 27 & Santana & 274,101 & 19,293 & 7.03 & 53.9 & 50.4 \\
\hline 28 & Tucuruvi & 463,262 & 28,464 & 6.4 & 45.6 & 57.4 \\
\hline 29 & Penha & 142,656 & 12,290 & 8.61 & 45.6 & 57.4 \\
\hline 30 & Tatuapé & 279,757 & 22,685 & 8.11 & 22.0 & 37.7 \\
\hline 31 & Casa Verde & 110,634 & 8,416 & 7.60 & 11.8 & 32.0 \\
\hline 32 & Saúde & 289,027 & 22,368 & 7.73 & 36.6 & 43.0 \\
\hline 33 & Limão & 86,034 & 5,223 & 6.07 & 22.9 & 50.5 \\
\hline 34 & Ibirapuera & 158,415 & 11,362 & 7.17 & 43.0 & 70.0 \\
\hline 35 & V. Jaguara & 71,641 & 4,138 & 5.79 & 56.1 & 73.0 \\
\hline 36 & V. Maria & 131,851 & 8,668 & 6.57 & 27.1 & 32.6 \\
\hline 37 & V. Prudente & 435,537 & 27,957 & 5.63 & 57.0 & 56.1 \\
\hline 38 & V. Formosa & 119,704 & 7,353 & 6.14 & 39.7 & 55.4 \\
\hline 39 & Cangaiba & 75,244 & 4,244 & 5.64 & 25.7 & 58.6 \\
\hline 40 & V. Matilde & 239,739 & 12,364 & 5.15 & 81.0 & 69.0 \\
\hline 41 & N. Senhora do $\sigma$ & 173,856 & 9,788 & 5.62 & 23.2 & 52.6 \\
\hline 42 & Jabaquara & 266,906 & 13,926 & 5.21 & 36.4 & 56.7 \\
\hline 43 & Butantan & 318,421 & 15,293 & 4.80 & 81.1 & 93.9 \\
\hline 44 & Pirituba & 117,773 & 6,521 & 5.53 & 55.1 & 55.2 \\
\hline 45 & V. N. Cachoeira & 37,411 & 2,044 & 5.46 & 38.2 & 52.3 \\
\hline 46 & Perus & 48,403 & 2,101 & 4.34 & 74.3 & 77.3 \\
\hline 47 & Matarazzo & 241,652 & 10,432 & 4.31 & 84,9 & 91,1 \\
\hline 48 & Brasilândia & 176,268 & 6,090 & 3.45 & 76.6 & 108.1 \\
\hline 49 & Jaraguá & 51,075 & 1,813 & 3.54 & 193.7 & 162.3 \\
\hline 50 & Itaquera & 414,888 & 14,405 & 3.47 & 159.3 & 134.5 \\
\hline 51 & Santo Amaro & 765,743 & 28,523 & 3.72 & 136.8 & 94.4 \\
\hline 52 & C. Socorro & 452,041 & 13,014 & 2.87 & 225.0 & 155.6 \\
\hline 53 & S.M. Paulis ta & 320,132 & 11,534 & 3.60 & 36.0 & 63.2 \\
\hline 54 & Guaianazes & 150,437 & 4,491 & 2.98 & 140.9 & 80.0 \\
\hline 55 & Parelheiros & 27,310 & 1,302 & 4.76 & 120.6 & 113.1 \\
\hline & S. Paulo & $8,493,226$ & 538,817 & 6.34 & 43.4 & 49.5 \\
\hline
\end{tabular}


and the poorer, and less urbanised areas, fewer elderly people.

An interesting finding was that the differences in the rates of increase for both the elderly and the total populations, in the period, reflected differences in the development of the sub-districts. For the purpose of understanding these differences on the light of the socio-economic differences and how they affect the elderly population, four sub-districts are taken as examples and analysed in more detail.

\section{Sub-district of "Sé" (see Table 4, n. 5)}

Situated in the old center of S. Paulo, this used to be a wealthy residential sub-district until the 1940s. Since then, "Sé" has become a poor commercial sub-district. In 1980, the average household income was US\$ 508 per month (see Table 1), but the infra-structure of sanitation built in the past remained good $-89.5 \%$ of the households had sewers (see Table 2). It had a very low population growth in the decade from 1970 to 1980 - the total population increased only $7.6 \%$, without any substantial increase in the elderly population (6.9\%) suggesting that elderly people probably migrated as the standards of living deteriorated. Nevertheless the proportion of elderly $(10.4 \%)$ remained well above the average for the city $(6.5 \%)$.

\section{Sub-district of "Aclimaçåo" (see Table 4, n. 8)}

This is also situated in the central area but has always been a wealthy residential sub-district. In 1980 , both the average household income (US\$ 784 per month) and the availability of sewers $(92.5 \%$ ) were high (see Tables 1 and 2 ). It showed a lower than average increase in the elderly and total popultions ( $30.1 \%$ and $12.8 \%$ respectively), although the former had a higher rate of increase, suggesting that the elderly have remained in this location. The proportion of elderly people in "Aclimaçåo" was, in fact, one of the highest among the sub-districts (11.9\%).

\section{Sub-district "Ibirapuera" (see Table 4 n. 34)}

Situated in the immediate outskirts of the central area of the city, this has become a wealthy residential sub-district. The average household income, in 1980, was US\$ 1,060 per month (see Table 1). Yet, it is also a newly developed area, in comparison with the old central part of the city, and had a relatively low availability of sewers $(83.7 \%$ ) (see Table 2). It showed the same average increase as the total population (43\%), but a well above average increase in the elderly population (70\%). This suggests that it was one of the receiving areas for the elderly migrating from the deteriorated areas of the center. The proportion of elderly people $(7.2 \%)$ was above the average (6.5\%).

\section{Sub-district "Capela do Socorro" (see Table 4 n. 52)}

Situated in the peripheral area of the city, this is a very poor area. The average household income was only US\$ 309 per month, in 1980 (see Table 1), and sanitary conditions were very poor - only $29 \%$ of the households were served by sewers in 1980 (see Table 2). In fact, this has been one of the main receiving areas for migrants arriving in S. Paulo, displaying an 'explosive' growth rate in its total population ( $225 \%$ in 10 years). In this particularly poor area, the proportion of elderly in the total population was one of the lowest in the city at $2.9 \%$.

\section{Defining the Homogeneous Areas}

In the light of the inter-relationship between income, sanitation and the age structure of the populations, the district of $S$. Paulo was stratified by means of the simultaneous use of the three variables for the purpose of grouping the 48 sub-districts in to three different socio-economic strata. They were placed in order according to the sum of sub-district's ranking in family income, availability of sewers and proportion of elderly (Table 5). The final geographical division, in 3 areas, again very much resembles the previous ones, as shown in Figure 5. Each area had the following characteristics:

1) Central area $A$ with high income (US\$ 1409 - US\$ 526), good availability of sewers $(97.2 \%-87.8 \%)$, and high proportion of people aged 65 and over $(8.91 \%-6.62 \%)$;

2) Intermediate area $B$ with median income (US\$ 1,063 - US\$ 410), fair availability of sewers $(92.1 \%-62.3 \%)$, and median proportion of people aged 65 and over $(8.06 \%-4.54 \%)$;

3) Peripheral area $C$ with low income (US\$ 457 - US\$ 296), poor availability of sewers 
TABLE 5

Sum of the rankings for income, sewers and proportion of elderly in lach sub-district

\begin{tabular}{|c|c|c|c|c|c|}
\hline Rank & Sub-district & $\begin{array}{l}\text { Rank by } \\
\text { Median } \\
\text { Family } \\
\text { Income }\end{array}$ & $\begin{array}{c}\text { Rank by } \\
\% \text { of } \\
\text { Households } \\
\text { with } \\
\text { Sewers }\end{array}$ & $\begin{array}{c}\text { Rank by } \\
\% \text { of } \\
\text { Elderly } \\
\text { in Total } \\
\text { Populat. }\end{array}$ & $\begin{array}{c}\text { Sum } \\
\text { of } \\
\text { Ranks }\end{array}$ \\
\hline 1 & C. César & 3 & 3 & 7 & 13 \\
\hline 2 & Consolação & 11 & 2 & 1 & 14 \\
\hline 3 & J. Paulista & 2 & 4 & 11 & 17 \\
\hline 4 & V. Mariana & 5 & 9 & 5 & 19 \\
\hline 5 & Sta. Cecília & 12 & 7 & 4 & 23 \\
\hline 6 & Indianópolis & 4 & 1 & 19 & 24 \\
\hline 7 & Pinheiros & 7 & 5 & 12 & 24 \\
\hline 8 & J. América & 1 & 12 & 14 & 27 \\
\hline 9 & Aclimação & 10 & 10 & 8 & 28 \\
\hline 10 & Perdizes & 8 & 6 & 16 & 30 \\
\hline 11 & Pari & 18 & 14 & 17 & 38 \\
\hline 12 & B. Vista & 14 & 8 & 17 & 39 \\
\hline 13 & B. Retiro & 17 & 19 & 3 & 39 \\
\hline 14 & Cambuci & 15 & 16 & 10 & 41 \\
\hline 15 & Belenzinho & 21 & 18 & 2 & 41 \\
\hline 16 & Lapa & 13 & 15 & 15 & 43 \\
\hline 17 & V. Madalena & 9 & 11 & 24 & 44 \\
\hline 18 & B. Funda & 19 & 21 & 9 & 49 \\
\hline 19 & Moóca & 20 & 22 & 13 & 55 \\
\hline 20 & Ibirapuera & 6 & 24 & 31 & 61 \\
\hline 21 & Sé & 25 & 17 & 20 & 62 \\
\hline 22 & Sta. Efigênia & 29 & 13 & 21 & 63 \\
\hline 23 & A. Moóca & 23 & 25 & 18 & 66 \\
\hline 24 & Liberdade & 22 & 20 & 26 & 68 \\
\hline 25 & Ipiranga & 24 & 23 & 23 & 70 \\
\hline 26 & Saúde & 16 & 30 & 28 & 74 \\
\hline 27 & V. Guilherme & 26 & 26 & 30 & 82 \\
\hline 28 & Brás & 34 & 26 & 22 & 82 \\
\hline 29 & C. Verde & 32 & 23 & 29 & 84 \\
\hline 30 & Santana & 27 & 27 & 32 & 86 \\
\hline 31 & Tatuapé & 28 & 33 & 27 & 88 \\
\hline 32 & Penha & 33 & 39 & 25 & 97 \\
\hline 33 & Limão & 36 & 27 & 36 & 99 \\
\hline 34 & V. Jaguara & 31 & 31 & 38 & 100 \\
\hline 35 & Tu curuvi & 35 & 38 & 34 & 107 \\
\hline 36 & Butantan & 30 & 35 & 45 & 110 \\
\hline 37 & Jabaquara & 37 & 32 & 42 & 111 \\
\hline 38 & V. Maria & 38 & 41 & 33 & 112 \\
\hline 39 & V. Prudente & 40 & 40 & 37 & 117 \\
\hline 40 & N.S. do "Ó" & 42 & 34 & 41 & 117 \\
\hline 41 & V. Formosa & 41 & 48 & 35 & 124 \\
\hline 42 & Pirituba & 39 & 46 & 40 & 125 \\
\hline 43 & V. N. Cachoeira & 46 & 37 & 43 & 126 \\
\hline 44 & Cangaiba & 43 & 39 & 47 & 129 \\
\hline 45 & V. Matilde & 44 & 42 & 44 & 130 \\
\hline 46 & Sto. Amaro & 45 & 44 & 46 & 135 \\
\hline 47 & Brasilândia & 48 & 43 & 47 & 138 \\
\hline 48 & C. Socono & 47 & 45 & 48 & 140 \\
\hline
\end{tabular}

$(78.0 \%-19.7 \%)$, and low proportion of people aged 65 and over $(4.12 \%-1.7 \%)$.

Table 6 shows that the three strata (homogeneous areas) had rather different population sizes - area $A$ with $17 \%$, area $B$ with $27 \%$ and area C with $56 \%$ of the total population of the district of S. Paulo. On the other hand, the percentage differences were not so pronounced for the population aged 65 and over - area A with $29 \%$, area $B$ with $33 \%$, and area C with $38 \%$ of the over 65 's of the district. Hence, the inclusion of the proportion of elderly people in the stratification process 


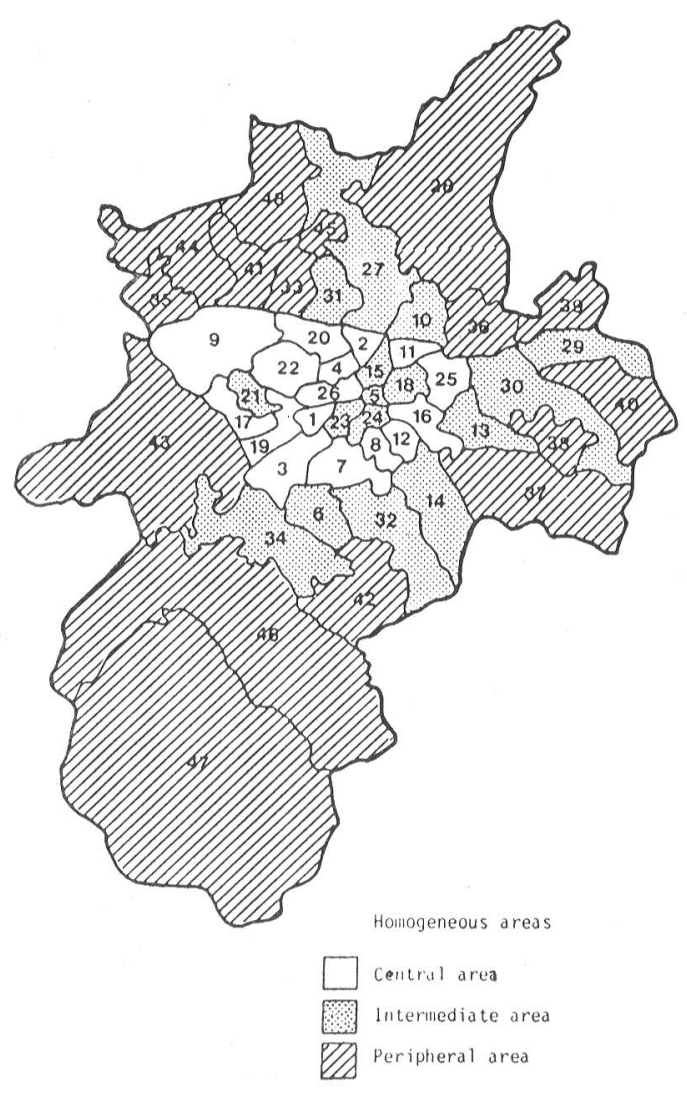

Fig. 5 - Division of the District of S. Paulo (48 sub-districts) in 3 homogeneous areas (16 sub-districts each) according to the average family income (US\$), availability of sewers (\%), and the proportion of people of 65 and over in the total population of each sub-district. produced a small stratum of high income households with almost the same number of elderly as the large stratum of low income households.

\section{Selecting the Sampling Areas}

Having divided the city into three areas, the idea was to select one sub-district of each as a sampling area, representing the whole stratum. With three sub-districts, one could assume that the spectrum of socio-economic variation in the universe of the elderly living in S. Paulo was represented in the sample.

The most important thing in the sampling process was to select as sampling areas the sub. districts that best represented the three homogeneous areas defined in the stratification process. That is to say, the most homogeneously wealthy sub-district in area A, as opposed, for instance, to the most homogeneously poor sub-district in area C. Thus the main criteria for the selection of the sub-districts were: to be the wealthiest among the wealthy and the poorest among the poor, for example. Such criteria led to the selection of the ten most representative sub-districts in each of the socio-economic strata, giving a total of 30 sub-districts which resulted from the selection process. Sub-districts that have become highly commercial or industrialised, were seen as less interesting for study purposes than those of a more residential character as the former tend to represent. very specific situations depending on the type of commerce or industry involved. In areas like Santa Efigenia and Se, for instance, less than $40 \%$ of the premises were residential. Such non-residential areas were likely to make the selection of the sample very difficult and to bias the results as the life style in such areas tends to be

TABLE 6

Total population and population aged 65 and over in three homogeneous areas according to family income, availability of sewers and proportion of elderly people in the total population.

\begin{tabular}{|c|c|c|c|c|c|}
\hline \multirow{3}{*}{$\begin{array}{l}\text { Homogeneous } \\
\text { Areas }\end{array}$} & \multicolumn{4}{|c|}{ Population } & \multirow{3}{*}{$\begin{array}{l}\text { Percentage } \\
\text { of } 65+\end{array}$} \\
\hline & \multicolumn{2}{|c|}{$65+$} & \multicolumn{2}{|c|}{ Total } & \\
\hline & No & $\%$ & N! & $\%$ & \\
\hline Central & 92,156 & 29.1 & $1,186,445$ & 16.7 & 7.8 \\
\hline Intermediate & 104,792 & 33.1 & $1,934,981$ & 27.2 & 5.4 \\
\hline Peripheral & 119,681 & 37.8 & $3,992,432$ & 56.1 & 3.0 \\
\hline São Paulo & 316,629 & 100.0 & $7,113,432$ & 100.0 & 4.5 \\
\hline
\end{tabular}


different from those in more residential areas. In this regard, a minimum of $70 \%$ of residential area in the sub-district was set as a selecting criterion for selection. From the 30 sub-districts already selected, based on the previous criteria, only 23 remained. Due to economic constraints, not all of the selected sub-districts were suitable for the survey, some had large populations of elderly and would inevitably demand a large sample if it was to be representative of the sub-district. Bearing this in mind, another exclusion criteria was introduced: the size of the elderly population. If the sub-district had more than 6,000 elderly people, it was excluded because the sampling fraction would be unattainable with the resources available. Of the 23 sub-districts still in the selection process, only 11 met this requirement.

Finally, it was decided that in all those subdistricts so far selected there was to be a visual inspection to determine which of them showed fewer socio-economic contrasts, eg. slums in the middle of a wealthy area, or a wealthy household estate in a poor area. Although these paradoxical clusters of households might not influence the average income of the sub-district, it could bias the analysis if randomly selected in the final sample of households. Such a criterion was applied by two independent observers who met afterwards to decide which was the sub-district in each area to be included in the sample, from among those already selected by the previous criteria.

Therefore, instead of making a random selection of one sub-district in each area, the selection was made based on a set of criteria as follows:

\section{Inclusion Criteria}

a) To be one of the top-10 sub-districts in group A of the ranking, or

b) To be one of the 5 sub-districts either above or below the median in group $\mathrm{B}$, or

c) To be one of the bottom 10 sub-districts in group $\mathrm{C}$ of the ranking.

\section{Exclusion Criteria}

a) If less than $70 \%$ of the households in the sub-district were residential units or,

b) If more than 6,000 people were aged 65 or over, thus exceeding the available resources if a representative sample were to be drawn, or

c) If the sub-district had obvious socio-economic contrasts at the visual inspection.

Eventually, "Aclimaçåo" was the sub-dis- trict selected as representative of the wealthy population living in the central area, with a high proportion of people aged 65 or over. "Vila Guilherme" was the one selected in the intermediate group and "Brasilandia" became the representative of the very poor and peripheral population (sited in the northern part of the city), with a low proportion of elderly people.

\section{Sampling Design}

Although the sample was not going to represent the whole city, one of the basic aims was to design a simple and sound methodology of sampling that would enable future expansion of the survey without losing comparability. It seemed more appropriate to use the methodology of the one household survey in the country regularly undertaken on a national basis (the equivalent of the GHS in Great Britain) - the "Pesquisa Nacional por Amostra de Domicilios" (PNAD) (IB$\left.G E^{4}, 1981\right)$ - as a starting point. Since 1976 the PNAD (introduced in 1967) has achieved national coverage and developed a fixed questionnaire format. The National Institute of Geography and Statistics Foundation (IBGE), responsible for the censuses in Brazil (as well as the PNAD), have adopted a methodology that was developed in the 50 's in the USA for continuous household surveys (US $^{13}, 1958$ ). Such a methodology was, in the 60 's, adapted to the reality of the Latin-American context by a joint effort of the United States Agency for International Development (USAID) and the Inter-American Statistical Institute (IASI) in an attempt to produce adequate data for comparisons among these countries.

Brazil had participated in the early experiments of this methodology which became known as the Atlantida Plan (US Bureau of Census ${ }^{12}$, 1966). The name is related to a hypothetical country having the same basic characteristics as any Latin-American country in which a national household survey is planned, all the calculations concerning the sampling are performed, results are produced and the analysis is made.

Like the American Census, the Atlantida methodology uses a stratified multi-stage random sample which takes the census tracks as the ultimate cluster from which to draw the households to be surveyed. The big advantage of this method is that it does not require a previous enumeration of the households in the whole of the study area, but only in the small clusters selected (US Bureau of Census ${ }^{12}$, 1966; IBGE, 1981). 


\section{Multistage Random Sample}

Although the present study demanded only a regional survey the Atlantida Plan methodology was still useful as a background. Each sub-district was considered a Primary Sampling Unit (US Bureau of Census $\left.^{12}, 1966\right)$ from which to draw a fixed proportion of clusters $(10 \%)$ - these clusters being the same as were used by the census, with a fairly standard size of about 300 households. Such clusters were selected by a proportionate random sample - based on the number of households - from a list of clusters in each subdistrict. Having selected the clusters, the sample of elderly people was randomly selected from a constructed list of elderly people living in each selected cluster. Every household in the selected clusters was enumerated by age and sex". From a list of people aged 65 or over, stratified by sex, and with a known address, a random sample was ta. ken, again using a fixed proportion (30\%). The overall sampling fraction for every sub-district was $3 / 100$ (Chart). As the survey aimed at a descriptive profile of the elderly living in different socio-economic environments, the choice of a sampling fraction was very much based on the availability of resources, with a view to achiering a reasonable Standard Error.

\section{DISCUSSION}

A sample of 303 elderly people selected by the methodology described above was interviewed at home by trained interviewrs. The instrument used was the BOMFAQ - Brazilian version of the OARS Multidimensional Functional Assessemnt Questionnaire - and covered five basic dimensions: socio-economic status, physical health, mental health, independence in the activities of daily living, and social integration. A full description of results are presented elsewhere (Ramos $\left.^{10}, 1987\right)$. For the purpose of analysing the validity of the methodology used, the most important finding of the survey concerned the significant differences found between the elderly living in the poor sub-district ("Brasilandia") and the wealthy sub-district ("Aclimaçåo"). The stratification process using the sub-districts as socioeconomic strata successfully selected totally different populations as regards the socio-economic

\section{TABLE 7}

Association between the sub-districts of residence of the elderly person and the per capita income in the household (US\$ per month) - percentage distribution.

\begin{tabular}{|c|c|c|c|c|}
\hline \multirow{2}{*}{ Variable } & \multicolumn{4}{|c|}{ Sub-district of residence } \\
\hline & Brasilândia & V. Guilherme & Aclimação & Total \\
\hline \multicolumn{5}{|c|}{$\begin{array}{l}\text { Per capita } \\
\text { income (US\$) }\end{array}$} \\
\hline$<50$ & 82 & 45 & 22 & 54 \\
\hline $50-99$ & 18 & 30 & 26 & 24 \\
\hline $100-250$ & 0 & 22 & 26 & 14 \\
\hline$>250^{\circ}$ & 0 & 3 & 26 & 8 \\
\hline Total & 100 & 100 & 100 & 100 \\
\hline Base $(\mathrm{N}=)$ & 297 & 119 & 97 & 81 \\
\hline
\end{tabular}

\footnotetext{
The enumeration was undertaken by a team of University students, trained and supervised in the field, who knocked at the door of every household in each of the selected clusters, asking whether or not there was an elderly person living in the place - aged 65 or more - and registering the name, age and sex of the person. The enumeration was undertaken on the basis of map of the clusters.
} 


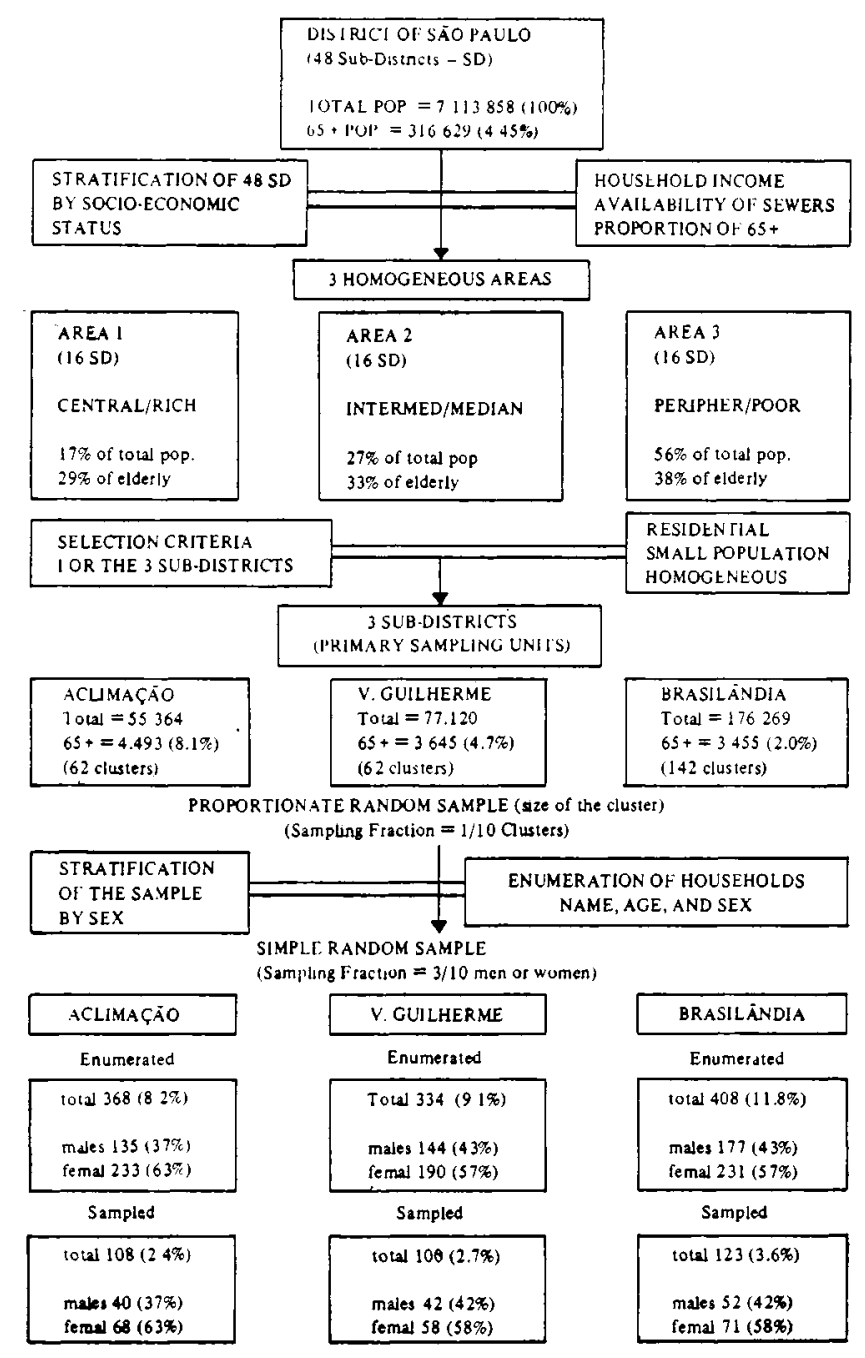

Chart - Multistage Cluster Sampling Stratified by Social Class and sex

status of the elderly. The average per capita income was as low as US\$ 32 per month in "Brasilândia", actually eight times lower than in "Aclimaçåo" - US\$ 233 per month. In "Brasilândia", in fact, none of the households had an average per capita income of more than US\$ 100 per month, compared with $25 \%$ of the houscholds in "Vila Guilherme" and 52\% in "Aclimaçåo"as shown in Table 7 ( $p<0.00001)$.

In "Brasilândia", for instance, the typical elderly person was a migrant from a rural area, illiterate and living in the place of the interview for less than ten years. The tendency in "Brasilândia" was for the elderly to be black, widowed, with a large family, living in very poor housing conditions with no sewers, with at least three other people in the household including children and grand-children.

In contrast, the typical elderly person in "Aclimaçåo" had an urban background, had at least a high-school degree and had lived in the place of the interview for more than ten years.

He or she tended to be white, married, with a relatively small family, living in good housing conditions with sewers, and sharing the dwelling with no more than one other person, usually the spouse (Ramos ${ }^{10}, 1987$ ).

The profile of the elderly in each sub-district appeared, in fact, to be a socio-economic profile. The implications of this may be far-reaching in terms of socio-economic analysis. A geographic stratification by socio-economic status makes the concept of social class more operational and encompasses the roles of income, personal assets, 
educational level, migration history, and housing conditions of the person's life. Public health policies can, thus, be directed towards target areas, which will demand specific policies which take the idiosyncrasies of each area into consideration. Moreover, such stratification overcomes the problems of classifying the elderly by socio-economic status using their occupation or income, considering that elderly people are no longer economically productive. From the epidemiological standpoint the results of this survey indicate that any relevant analysis of the well-being of the elderly has to consider as the main independent variable their socio-economic status.

Interestingly enough, the elderly themselves seemed a good indicator of the socio-economic status of the population, as the proportion of elderly in the total population showed a good correlation with the median family income and availability of sanitation in the area. Such a strong association suggests that the socio-economic stratification can be further simplified by using the elderly themselves as an indicator. Areas with a high proportion of elderly people, for instance, are likely to be areas where the majority of the population, at least the elderly population, have high incomes, good housing conditions and good education and basic amenities. Whether this stratification holds true for other cities and indeed other countries is a matter that deserves further investigation.

\section{ACKNOWLEDGEMENTS}

To Alexandre Kalache (London University), to Gerda Fillenbaum (Duke University), and to Jenny Roberts (London University) for their thoughtful comments on early versions of this article. To the "Conselho Nacional de Desen. volvimento Cientifico e Tecnologico - CNPq, the 'Fundação de Amparo à Pesquisa do Estado de São Paulo'-FAPESP, and the British Council for the financial support received.

RAMOS, L.R. \& GOIHMAN, S. Estratificação geográfica por nivel sócio-económico: metodologia utilizada em um inquérito domiciliar com idosos residentes em São Paulo, Brasil. Rev. Saúde públ, S. Paulo, 23: 478-92, 1989.

RESUMO: Em países como o Brasil é sempre problemático conseguir-se uma amostra populacional randomisada e representativa dada a inexistencia de um catálogo atualizado e global da populaçăo residente na comunidade. Discute-se a metodologia de estratificação geográfica por nivel scccio-económico utilizada para conseguir uma amostra randomisada em múltiplos estágios de uma populaçáo de idosos residentes na cidade de Săo Paulo. O estudo aponta para o fato de a proporçăo de idosos na população total de uma determinada área da cidade ter se mostrado uma variável com poder discriminante do nível sócio-económico da populaçāo. Discute-se a validade do método de estratificação a partir dos dados coletados no inquérito.

DESCRITORES: Populaçăo urbana. Idosos. Amostragem. Métodos. Fatores sócio-económicos.

\section{REFERENCES}

1. FUNDAÇĀO IBGE. Censo demagráfico: Säo Paulo. Rio de Janeiro, 1973. v.1, t.18, pt. 3. ( $8^{\circ}$ Recenseámento Geral do Brasil, 1970).

2. FUNDAÇĀO IBGE. Censo demográfico. Dados distritais: São Paulo. Rio de Janeiro, 1982. v.1, t.3, n.17. (9º Recenseamento Geral do Brasil, 1980).

3. FUNDAÇĀO IBGE. Censo demogrófico. Familias e domictlios: Sāo Paulo. Rio de Janeiro, 1983.v.1,t.6, n.19. ( $9^{\circ}$ Recenseamento (reral do Brasil, 1980).

4. FUNDAÇĀO IBGE. Metodologia da Pesquisa Nacional por Amostra de Domicllios (PNAD) na decada de 70. Rio de Janeiro, 1981.

5. FUNDAÇÄO IBGE. Indicadores sociais: tabelas selecionadas. Rio de Janeiro, 1984. v.2.
6. FUNDAÇĀO SEADE. Anub́rio Estatistico do Estado de São Paulo: 1983. São Paulo, 1987.

7. GOVERNO DO ESTADO DE SÃO PAULO. Áreas homogeneas: Município de São Paulo. São Paulo, 1976. (Estudos e Pesquisas 14).

8. KALACHE, A.; VERAS, R.P.; RAMOS, L.R. O envelhecimento da população mundial: um desafio novo. Rev. Saúde públ, S. Paulo, 21:200-10, 1987.

9. MONTEIRO, C.A.; BENICIO, M.H.D'A.; BALDIJĀO, M.F.A. Mortalidade no primeiro ano de vida e a distribuição de renda e de recursos públicos de saude, São Paulo, Brasil. Rev. Saúde públ, S. Paulo. 14:515-39, 1980. 
10. RAMOS, L.R. Growing old in Såo Paulo, Brazil: assessment of health status and social support of elderly people from different socio-economic strata living in the community. London, 1987. [PhD Dissertation-London School of Hygiene and Tropical Medicine. University of London].

11. RAMOS, L.R:; VERAS, R.P.; KALACHE, A. Envelhecimento populacional: uma realidade brasileira. Rev. Saúde públ, S. Paulo, 21:211-24, 1987.

12. US BUREAU OF THE CENSUS. Atlantida: a case study in household sample surveys - unit IV sample design. Washington, D.C., 1966. (Series ISPO 1, No 1-E).

13. US NATIONAL HEALTH SURVEY AND THE
BUREAU OF CENSUS. The statistical design of the health household-interview survey. Washington, D.C., 1958.

14. VERAS, R.P.; RAMOS, L.R.; KALACHE, A. Crescimento da população idosa no Brasil: transformações e conseqüencias na sociedade. Rev. Saúde públ, S. Paulo, 21:225-33, 1987.

Recebido para publicação em 5/6/1989 Aprovado para publicoção em 15/8/1989 